\title{
PERBANDINGAN POLA SENSITIVITAS BAKTERI TERHADAP ANTIBIOTIK DI RUANG ICU DAN RUANG RAWAT INAP NON ICU DI RUMAH SAKIT UMUM DAERAH Dr. H. ABDUL MOELOK BANDAR LAMPUNG
}

\author{
Hidayat $^{1}$, Abdurrohman Izzuddin ${ }^{2}$, Sanjoto Santibudi ${ }^{2}$, Sari Novpriani ${ }^{3}$
}

${ }^{1}$ Instalasi Laboratorium Patologi Klinik RSUD Dr. H. Abdul Moeloek Bandar Lampung

${ }^{2}$ Staf Pengajar, Fakultas Kedokteran, Universitas Malahayati, Lampung

${ }^{3}$ Mahasiswa Kedokteran, Fakultas Kedokteran, Universitas Malahayati, Lampung

\begin{abstract}
Comparison Of Bacterial Sensitivity Patterns to Antibiotics In ICU And Non ICU Inpatient Rooms at the Regional General Hospital Dr. H. Abdul Moeloek In Bandar Lampung. Irrational or more irrational use of antibiotics can lead to resistance and multi-trug resistance in bacteria. The İCU room is one of the wards with more use of antibiotics than other wards. This is what causes multi-drug resistant bacteria to be found in the ICU. to find out whether there is a difference in the pattern of bacterial sensitivity to antibiotics in the ICU and non-ICU inpatients at the Regional General Hospital Dr. H Abdul Moeloek Bandar Lampung for the period July-December 2019. Type This research is a descriptive analytic study with a retrospective approach. The sample of this study is the results of the retrieval culture of 525 patients in the ICU and non-ICU inpatients who received antibiotic therapy for the period July-December 2019, obtained from the Microbiology Laboratory of the Clinical Pathology Installation at Dr.H Abdul Moeloek Bandar Lampung The statistical test used the univariate test. The data is displayed in the form of a frequency distribution table. The results of the culture and resistance test for the JulyDecember 2019 period were shown, in the ICU room the highest bacteria, namely Klebsiella pneumoniae (18) were still sensitive to Meropenem antibiotics (91,7\%) and in non-ICU inpatient rooms the highest service was obtained, namely Staplylococcus sp $(23 \%)$ which is still sensitive to Meropenem (90,2\%).
\end{abstract}

Keywords: Bacterial Sensitivity Patterns, ICU, Non ICU

Abstrak: Perbandingan Pola Sensitivitas Bakteri Terhadap Antibiotik Di Ruang Icu Dan Ruang Rawat Inap Non Icu Di Rumah Sakit Umum Daerah Dr.H.Abdul Moelok Bandar Lampung. Penggunaan antibiotik yang tidak rasional atau secara berlebih dapat mengakibatkan terjadinya resistensi dan multi drug resisten pada bakteri. Ruang ICU merupakan salah satu ruang rawat dengan penggunaan antibiotik yang lebih banyak selain ruang rawat lainnya. Hal ini yang menyebabkan sering ditemukan bakteri yang sudah multi drug resisten di ruang ICU. untuk mengetahui apakah terdapat perbedaan pola sensitivitas bakteri terhadap antibiotik di ruang ICU dan ruang rawat inap Non ICU Rumah Sakit Umum Daerah Dr.H.Abdul Moeloek Bandar Lampung periode Juli-Desember 2019. Jenis penelitian ini adalah deskriptif analitik dengan pendekatan retrospektif. Sampel penelitian ini adalah hasil pemeriksaan kultur resistensi dari 525 pasien di ruang ICU dan ruang rawat inap Non ICU yang mendapat terapi antibiotik periode Juli-Desember 2019. Diperoleh dari Laboratorium Mikrobiologi Instalasi Patologi Klinik RSUD Dr.H.Abdul Moeloek Bandar Lampung. Uji statistik menggunakan uji univariat. Data ditampilkan dalam bentuk tabel distribusi frekuensi. Hasil uji kultur dan resistensi periode JuliDesember 2019 didaptkan, pada ruang ICU didapatkan bakteri tertinggi, yaitu Klebsiella pneumoniae (18\%) masi sensitif terhadap antibiotik Meropenem $(91,7 \%)$ dan pada ruang rawat inap Non ICU didapatkan bakteri tertinggi, yaitu Staphylococcus sp (23\%) yang masi sensitif terhadap Meropenem $(90,2 \%)$.

Kata Kunci: Pola Sensitivitas Bakteri, ICU, Non ICU

\section{PENDAHULUAN}

Antibiotik berasal dari kata "anti

dan bios" yang berarti hidup atau kehidupan. Antibiotik merupakan golongan senyawa alami atau sintesis yang memiliki kemampuan untuk menekan atau menghentikan proses biokimia di dalam suatu organisme, 
khususnya proses infeksi bakteri. Antibiotik juga dapat membunuh atau melemahkan suatu organisme, seperti bakteri, parasit, atau jamur (Utami, 2012).

Penggunaan antibiotik yang tidak rasional dapat mengakibatkan peningkatan resistensi bakteri terhadap antibiotik di rumah sakit, sehingga dengan meningkatnya resistensi bakteri terhadap antibiotik maka dapat mempersulit proses pengobatan. Beberapa jenis bakteri yang sering mengalami resistensi terhadap antibiotik, yaitu Staphylococcus aureus terhadap metisilin dan vankomisin, Staphylococcus epidermidis terhadap metisilin, Enterococci terhadap vankomisin dan bakteri spektrum luas terhadap antibiotik golongan beta laktam (Wiguna, 2016).

Angka kematian akibat resistensi antibiotik sampai saat ini sekitar 700.000 orang per tahun. Pada tahun 2050 diperkirakan ada 10 juta kematian per tahun akibat resistensi antibiotik bahkan lebih tinggi dari angka kematian yang diakibatkan oleh kanker (Kemenkes RI, 2019). Data menunjukkan bahwa $86,1 \%$ rumah tangga Indonesia menyiapkan antibiotik tanpa resep. Di Provinsi Lampung 92\% rumah tangga menyimpan antibiotik, tertinggi kedua di Indonesia setelah Kalimantan Tengah (93,4\%) (Riskesdas, 2013).

Sebuah studi yang dilakukan di Indonesia tahun 1990-2010 menunjukkan bahwa resistensi antibiotik hampir terjadi pada semua bakteri patogen. Hal ini merupakan dampak negatif dari pemakaian antibiotik yang irasional serta penggunaan antibiotik dengan indikasi yang tidak jelas, bahkan disertai dosis yang tidak tepat dalam jangka waktu lama (WHO, 2011).

Rumah sakit merupakan tempat untuk menjalani perawatan. Namun, rumah sakit juga dapat menjadi sarang bagi berbagai macam bakteri penyebab infeksi (Nengah, 2016). Intensive Care Unit (ICU) adalah suatu bagian dari rumah sakit yang mandiri dengan staf khusus dan perlengkapan yang khusus dengan tujuan untuk terapi pasien yang menderita penyakit, cedera atau penyulit-penyulit yang mengancam nyawa atau potensial mengancam nyawa dengan prognosis dubia (Kemenkes RI, 2010).

Infeksi terutama terjadi di ruang rawat intensif atau intensive care unit (ICU). Hal ini terjadi karena ICU terkontaminasi oleh bakteri dan mikroba lain, sementara pasien di ICU sering kali berada dalam keadaan imunocompromise, menjalani tindakan dan monitoring secara invasive, dan sering berkontak dengan staf rumah sakit serta keluarga pasien, sehingga dapat menyebabkan infeksi nosokomial. Tingginya penggunaan antibiotik juga menyebabkan resistensi yang dapat menyulitkan terapi pengobatan dan mempermudah penyebaran infeksi (Nenggah, 2016).

Penelitian yang dilakukan oleh $\mathrm{Ni}$ Nengah (2016) di Denpasar menunjukkan bahwa mikroba yang banyak ditemukan pada pasien yang dirawat di ICU yaitu Pseudomonas aeruginosa $(18 \%)$, Acinetobacter baumanii (18\%), Staphylococcus $s p$ koagulase negatif $(12 \%)$, Candida $s p$ $(10 \%)$, dan Staphylococcus aureus (8\%). Dari uji sensitivitas antibiotik secara umum didapatkan bahwa bakteri gram positif sensitif terhadap antibiotik vancomycin dan linezolid, sedangkan bakteri gram negatif sensitif terhadap antibiotik sulbactam, piperacillin, meropenem dan cefepime.

Penelitian yang dilakukan oleh Mutia Zahra (2018) di Bandar Lampung menunjukkan bahwa bakteri terbanyak berada di ruang ICU dengan persentase $16,8 \%$ dari 45 sampel. Hasil pemeriksaan uji resistensi antibiotik menunjukkan bahwa bakteri Staphylococcus sp resisten terhadap antibiotik penisilin, ampisilin, amoksilin, ceftriaxone, ceftazidime dan cefotaxime. Bakteri Pseudomonas $s p$ resisten terhadap antibiotik penisilin, ampisilin, amoksilin, ceftriaxone dan tetrasiklin. Bakteri Klebsiella sp resisten terhadap antibiotik penisilin, ampisilin, amoksilin, ceftriaxone dan tetrasiklin. Bakteri Proteus $s p$ resisten terhadap antibiotik penisilin, ampisilin, amoksilin, ceftriaxone dan cefotaxime. Bakteri Escherichia coli resisten terhadap antibiotik penisilin, amoksilin, ampisilin, ceftriaxone dan tetrasiklin. Hasil dari uji sensitivitas terhadap bakteri didapatkan 
pola bakteri yang telah resisten terhadap beberapa antibiotik, seperti penisilin $(100 \%)$, ampisilin (83\%), amoksilin $(78,6 \%)$, cefotaxime $(33 \%)$, tetrasiklin $(28,6 \%)$, ceftriaxone $(22,7 \%)$. Antibiotik yang masih sensitif yaitu meropenem (75\%).

Penelitian yang dilakukan oleh $\mathrm{M}$. Agung Kurnia (2019) di Bandar Lampung menunjukkan bahwa pola penyebaran jenis bakteri yang tumbuh di ruangan non ICU paling banyak

\section{METODE}

Penelitian ini dilakukan di bulan Desember 2020 - Januari 2021 di Laboratorium Patologi Klinik RSUD Dr. $\mathrm{H}$. Abdul Moeloek Bandar Lampung. Penelitian ini termasuk penelitian deskriptif analitik dengan pendekatan retrospektif. Sampel diambil

HASIL

Jenis sampel terbanyak dari spesimen pus $41,1 \%$ dan jenis sampel adalah bakteri Enterobacter cloacea (33\%). Data pola resisten bakteri terhadap antibiotik di ruang ICU Abdul Moeloek periode Januari-Maret 2019 menunjukkan bahwa bakteri Enterobacter cloacae memiliki sensitivitas tertinggi terhadap antibiotik amikacin yaitu $37(100 \%)$, dan di ruang Non ICU bakteri Enterobacter $s p$ memiliki sensitivitas tertinggi terhadap antibiotik amikacin yaitu $67(100 \%)$.

menggunakan teknik Purposive Sampling yang mengara pada kriteria inklusi dan eksklusi. Sampel yang didapat sebanyak 525 sampel. Data di analisis menggunakan analisis univariat untuk memperoleh gambaran pola kuman dan pola sensitivitas bakteri terhadap antibiotik.

terkecil dari spesimen feses $1,1 \%$ terlihat pada tabel 1 .

Tabel 1. Distribusi jenis sampel berdasarkan spesimen.

\begin{tabular}{lcc}
\hline Jenis Sampel & Jumlah & \% \\
\hline Pus & 216 & 41,1 \\
Sputum & 146 & 27,8 \\
Darah & 101 & 19,2 \\
Urin & 34 & 6,1 \\
Cairan Tubuh & 24 & 4,6 \\
Feses & 6 & 1,1 \\
\hline Total & $\mathbf{5 2 5}$ & $\mathbf{1 0 0}$ \\
\hline
\end{tabular}

$\begin{array}{cl}\begin{array}{l}\text { Distribusi pemeriksaan kultur } \\ \text { berdasarkan asal ruangan terlihat }\end{array} & \begin{array}{l}\text { ICU 22,5\% dan yang terendah terdapat } \\ \text { di ruangan PICU } 1,1 \% \text {. Jenis sampel } \\ \text { pada tabel 2. }\end{array} \\ \begin{array}{c}\text { Pada tabel } 2 \text { di atas terlihat dari } \\ \text { yaitu ruang Puri Betik Hati } 10,7 \% \text { dan }\end{array} \\ \begin{array}{c}525 \text { sampel di ruangan ICU dan ruang } \\ \text { terendah adalah ruang Mahan Munyai }\end{array} \\ \text { rawat inap Non ICU, Sampel di ruangan } & 0,2 \% .\end{array}$

Tabel 2. Distribusi pemeriksaan kultur berdasarkan asal ruangan.

\begin{tabular}{llcc}
\hline & \multicolumn{1}{c}{$\begin{array}{c}\text { Asal } \\
\text { Sampel }\end{array}$} & Jumlah & \% \\
\hline I & Ruang ICU & & \\
\hline & ICU & 118 & 22,5 \\
& NICU & 9 & 1,7 \\
& PICU & 6 & 1,1 \\
\hline II & Instalasi Rawat Jalan & & 7,0 \\
\hline & IRJ & 37 & 10,7
\end{tabular}


Alamanda

Melati

Peri

Kenanga

Murai

Kutilang

Mawar

4,2

Anyelir

4,0

Gelatik

3,2

VIP A

3,0

Delima

3,0

IGD

Kemuning

1,9

Bogenvil

1,3

Tulip

Seruni

4

R/14

0,6

Nuri

0,6

Isolasi

0,6

Anggrek

3

0,4

Mahan Munyai

Total

3

0,4

2

0,2

Tabel 3. Distribusi jenis bakteri yang tumbuh di ruang ICU

\begin{tabular}{|c|c|c|c|}
\hline No. & Bakteri & Jumlah & $\%$ \\
\hline 1. & Klebsiella pneumoniae & 24 & 18,0 \\
\hline 2. & Staphylococcus sp & 20 & 15,0 \\
\hline 3. & Escherichia coli & 15 & 11,3 \\
\hline 4. & Enterobacter cloacae & 12 & 9,0 \\
\hline 5. & Pseudomonas aeruginosa & 10 & 7,5 \\
\hline 6. & Acinetobacter baumannii & 6 & 4,5 \\
\hline 7. & Enterobacter sp & 5 & 3,8 \\
\hline 8. & Pseudomonas Iuteola & 5 & 3,8 \\
\hline 9. & Pseudomonas sp & 5 & 3,8 \\
\hline 10. & Klebsiella $s p$ & 4 & 3,0 \\
\hline 11. & Proteus $s p$ & 3 & 2,3 \\
\hline 12. & Proteus mirabilis & 3 & 2,3 \\
\hline 13. & Burkholderia cepacia & 3 & 2,3 \\
\hline 14. & Citrobacter freundii & 2 & 1,5 \\
\hline 15. & Leclercia adecarboxylata & 2 & 1,5 \\
\hline 16. & Enterobacter aerogenes & 2 & 1,5 \\
\hline 17. & Serratia fonticola & 2 & 1,5 \\
\hline 18. & Pasteurella pneumotropica & 2 & 1,5 \\
\hline 19. & Staphylococcus aureus & 1 & 0,8 \\
\hline 20. & Enterococcus faecium & 1 & 0,8 \\
\hline 21. & Staphylococcus epidermidis & 1 & 0,8 \\
\hline 22. & Serratia marcescens & 1 & 0,8 \\
\hline 23. & Providencia stuartii & 1 & 0,8 \\
\hline 24. & Pseudomonas fluorescens & 1 & 0,8 \\
\hline 25. & Sphigomonas thalpophilum & 1 & 0,8 \\
\hline 26. & Burkholderia pseudoomallei & 1 & 0,8 \\
\hline Total & 133 & 100 & \\
\hline
\end{tabular}


Dari tabel 3 dapat diketahui bahwa dari 133 sampel di ruang ICU di Rumah Sakit Umum Daerah Dr.H.Abdul Moeloek Bandar Lampung, di dapatkan jenis pertumbuhan bakteri tertinggi adalah bakteri Klebsiella pneumoniae $18,0 \%$, Staphylococcus sp $15 \%$ bakteri Escherichia coli 11,3\%.

\section{Tabel 4. Distribusi jenis bakteri yang tumbuh di ruang rawat inap Non ICU}

\begin{tabular}{|c|c|c|c|}
\hline No & Bakteri & Jumlah & $\%$ \\
\hline 1. & Staphylococcus sp & 82 & 23,1 \\
\hline 2. & Escherichia coli & 39 & 11,0 \\
\hline 3. & Klebsiella pneumoniae & 32 & 9,0 \\
\hline 4. & Enterobacter cloacae & 31 & 8,7 \\
\hline 5. & Enterobacter sp & 22 & 6,2 \\
\hline 6. & Proteus mirabilis & 17 & 4,8 \\
\hline 7. & $\begin{array}{l}\text { Pseudomonas } \\
\text { aeruginosa }\end{array}$ & 14 & 3,9 \\
\hline 8. & Pseudomonas luteola & 10 & 2,8 \\
\hline 9. & $\begin{array}{l}\text { Acinetobacter } \\
\text { baumannii }\end{array}$ & 10 & 2,8 \\
\hline 10. & $\begin{array}{l}\text { Sphingomonas } \\
\text { paucimobilis }\end{array}$ & 9 & 2,5 \\
\hline 11. & Enterobacter aerogenes & 8 & 2,3 \\
\hline 12. & Pseudomonas sp & 7 & 2,0 \\
\hline 13. & Proteus $s p$ & 6 & 1,7 \\
\hline 14. & $\begin{array}{l}\text { Staphylococcus } \\
\text { haemolyticus }\end{array}$ & 6 & 1,7 \\
\hline 15. & Providencia rettgeri & 6 & 1,7 \\
\hline 16. & Serratia marcescens & 6 & 1,7 \\
\hline 17. & Serratia fonticola & 5 & 1,4 \\
\hline 18. & Staphylococcus aureus & 4 & 1,1 \\
\hline 19. & Serratia liquefaciens & 4 & 1,1 \\
\hline 20. & Burkholderia cepacia & 4 & 1,1 \\
\hline 21. & $\begin{array}{l}\text { Raoultella } \\
\text { ornithinolytica }\end{array}$ & 3 & 0,8 \\
\hline 22. & Staphylococcus sciuri & 3 & 0,8 \\
\hline 23. & $\begin{array}{l}\text { Pseudomonas } \\
\text { oryzihabitans }\end{array}$ & 2 & 0,6 \\
\hline 24. & Klebsiella Sp & 2 & 0,6 \\
\hline 25. & Acinetobacter iwoffii & 2 & 0,6 \\
\hline 26. & Alcaligenes faecalis & 2 & 0,6 \\
\hline 27. & Salmonella typhi & 1 & 0,3 \\
\hline 28. & Cronobacter sakazakii & 1 & 0,3 \\
\hline 29. & Staphylococcus capitis & 1 & 0,3 \\
\hline 30. & Enterococcus faecium & 1 & 0,3 \\
\hline 31. & $\begin{array}{l}\text { Staphylococcus } \\
\text { epidermidis }\end{array}$ & 1 & 0,3 \\
\hline 32. & Staphylococcus lentus & 1 & 0,3 \\
\hline 33. & Staphylococcus xylosus & 1 & 0,3 \\
\hline 34. & $\begin{array}{l}\text { Staphylococcus } \\
\text { saprophyticus }\end{array}$ & 1 & 0,3 \\
\hline 35. & Citrobacter freundii & 1 & 0,3 \\
\hline 36. & Citrobacter youngae & 1 & 0,3 \\
\hline 37. & Proteus hauseri & 1 & 0,3 \\
\hline 38. & Yersinia kristensenii & 1 & 0,3 \\
\hline 39. & Klebsiella oxytoca & 1 & 0,3 \\
\hline 40. & Citobacter koseri & 1 & 0,3 \\
\hline
\end{tabular}




\begin{tabular}{llc} 
41. $\begin{array}{l}\text { Pasteurella } \\
\text { pneumotropica }\end{array}$ & 1 & 0,3 \\
42. Marganella morganii & 1 & 0,3 \\
43. Serratia ocloriferi & 1 & 0,3 \\
44. Pseudomonas & 1 & 0,3 \\
$\begin{array}{l}\text { fluorescens } \\
\text { 45. Stenotrophomonas } \\
\text { mata filii }\end{array}$ & 1 & 0,3 \\
\hline \multicolumn{1}{c}{ Total } & $\mathbf{3 5 5}$ & $\mathbf{1 0 0}$ \\
\hline
\end{tabular}

Dari tabel 4 di atas dapat diketahui bahwa dari 355 sampel di ruang rawat inap Non ICU di Rumah Sakit Umum Daerah Dr. H. Abdul Moeloek Bandar Lampung, di dapatkan jenis pertumbuhan bakteri tertinggi adalah bakteri Staphylococcus sp 23,1\%, Escherichia coli $11 \%$ dan Klebsiella pneumoniae $9 \%$.

Tabel 5. Pola sensitivitas bakteri terhadap antibiotik di ruang ICU

\begin{tabular}{|c|c|c|c|c|c|c|}
\hline No & Antibiotik & $\begin{array}{c}\text { Klebsiella } \\
\text { Pneumoniae } \\
\text { (24) }\end{array}$ & $\begin{array}{l}\text { Staphylococ } \\
\text { cus sp (20) }\end{array}$ & $\begin{array}{c}\text { Escheric } \\
\text { hia coli } \\
\text { (15) }\end{array}$ & $\begin{array}{l}\text { Enterobacter } \\
\text { cloacae (12) }\end{array}$ & $\begin{array}{c}\text { Pseudomonas } \\
\text { aeruginosa } \\
\text { (10) }\end{array}$ \\
\hline & & S (\%) & S (\%) & S(\%) & S (\%) & S(\%) \\
\hline $\begin{array}{l}1 \\
2\end{array}$ & $\begin{array}{l}\text { ESBL } \\
\text { Ampicillin }\end{array}$ & & & & & \\
\hline 3 & Sulbactam & $1(4,2)$ & & $2(14,3)$ & $2(6,7$ & \\
\hline 4 & Piperacillin & $8(33,3)$ & $7(35)$ & $\begin{array}{c}12 \\
(85,7)\end{array}$ & $6(50)$ & $5(50)$ \\
\hline 5 & Cefazolin & & & $2(14,3)$ & $3(25)$ & \\
\hline 6 & Ceftazidime & & & $5(33,3)$ & $4(33,3)$ & $6(60)$ \\
\hline 7 & Ceftriaxone & & & $2(13,3)$ & $4(33,3)$ & $1(50)$ \\
\hline 8 & Cefepime & $6(25)$ & $3(15)$ & $5(33,3)$ & $5(41,7)$ & $7(70)$ \\
\hline 9 & Azteonam & & & $3(20)$ & $7(58,3)$ & $4(40)$ \\
\hline 10 & Ertapenem & $14(58,3)$ & & $\begin{array}{c}13 \\
(86,7)\end{array}$ & $10(83,3)$ & \\
\hline 11 & Meropenem & $22(91,7)$ & & $\begin{array}{c}15 \\
(100)\end{array}$ & $11(91,7)$ & $8(80)$ \\
\hline 12 & Amikacin & $21(87,5)$ & $14(70)$ & $\begin{array}{c}15 \\
(100)\end{array}$ & $11(91,7)$ & $10(100)$ \\
\hline 13 & Gentamicin & $9(37,5)$ & $16(80)$ & $\begin{array}{c}13 \\
(86,7)\end{array}$ & $9(75)$ & $9(90)$ \\
\hline 14 & Ciproflokxacin & $2(8,3)$ & $6(30)$ & $5(33,3)$ & $7(58,3)$ & $7(70)$ \\
\hline 15 & Tigecycline & $21(87,5)$ & $4(20)$ & $\begin{array}{c}14 \\
(93,3)\end{array}$ & $9(75)$ & \\
\hline 16 & Nitrofurantion & $5(20,8)$ & & $9(60)$ & $2(16,7)$ & 0 \\
\hline 17 & Sulfamethoxazole & $10(41,7)$ & & $7(56,7)$ & $9(75)$ & $1(50)$ \\
\hline 18 & Clindamicin & & $2(10)$ & $2(100)$ & & \\
\hline 19 & Tetraciklin & & $7(35,5)$ & $1(50)$ & & \\
\hline 20 & Eritromicin & & $8(40)$ & & & \\
\hline 21 & Clavulanic acid & & $1(5)$ & & & \\
\hline 22 & Cefotaxime & & $1(5)$ & & & \\
\hline 23 & Cefedroxil & & $1(5)$ & & & \\
\hline 24 & Netilmicin & & $9(45)$ & & & \\
\hline 25 & Cepoperazine & & $5(25)$ & & & \\
\hline 26 & Amoxicillin & & $3(15)$ & & & \\
\hline 27 & Sulbactam & & $7(35)$ & & & \\
\hline
\end{tabular}


Dari tabel 6 di atas dapat diketahui pola sensitivitas bakteri terhadap antibiotik di ruang rawat inap Non ICU Rumah Sakit Dr. H. Abdul Moeloek Bandar Lampung periode JuliDesember 2019 dari 45 bakteri, Staphylococcus sp memiliki sensitivitas tertinggi terhadap antibiotik meropenem 90,2\%, amikacin 86,6\%, gentamicin $47,6 \%$ dan memiliki sensitivitas terendah terhadap antibiotik eritromicin dan cefedroxil 2,4\%. Escherichia coli memiliki sensitivitas tertinggi terhadap antibiotik amikacin $100 \%$, meropenem 94,9\%, tigecyline $92,3 \%$ dan memiliki sensitivitas terendah terhadap antibiotik apicillin $2,6 \%$. Klebsiella pneumoniae memiliki sensitivitas tertinggi terhadap antibiotik amikacin 85,5\%, meropenem 84,4\%, tigecyline $83,9 \%$ dan memiliki sensitivitas terendah terhadap antiiotik nitrofurantion $22 \%$. Enterobacter cloacae memiliki sensitivitas tertinggi terhadap antibiotik amikacin $100 \%$, ertapenem dan meropenem 93,5\% dan memiliki sensitivitas terendah terhadap antibiotik piperacilin 9,7\%. Enterobacter $s p$ memiliki sensitivitas tertinggi terhadap antibiotik meropenem dan amikacin 90,9\%, netilmicin $85,7 \%$ dan memiliki sensitivitas terendah terhadap antibiotik piperacilin, tigecycline, sulfamethoxazole $4,55 \%$ dan antibiotik eritromicin $4,8 \%$.

Tabel 7. Perbedaan pola kuman di ruang ICU dan ruang Rawat inap Non ICU

\begin{tabular}{cll}
\hline No & \multicolumn{1}{c}{ Bakteri } \\
\cline { 2 - 3 } & \multicolumn{1}{c}{ Ruang ICU } & \multicolumn{1}{c}{ Ruang Rawat Inap Non ICU } \\
\hline 1. & Klebsiella pneumoniae $(18 \%)$ & Staphylococcus $s p(23,1 \%)$ \\
2. & Staphylococcus $s p(15 \%)$ & Escherichia coli $(11 \%)$ \\
3. & Escherichia coli $(11,3 \%)$ & Klebsiella pneumoniae $(9 \%)$ \\
4. & Enterobacter cloacae $(9 \%)$ & Enterobacter cloacae $(8,7 \%)$ \\
5. & $\begin{array}{l}\text { Pseudomonas aeruginosa } \\
\text { (75\%) }\end{array}$ & Enterobacter sp $(6,2 \%)$ \\
\hline
\end{tabular}

\begin{tabular}{lllll}
\multicolumn{1}{c}{ Berdasarkan tabel $7 \mathrm{di}$ atas } & ICU, yaitu bakteri Klebsiella \\
menunjukkan bahwa terdapat & $\begin{array}{l}\text { pneumoniae sedangkan yang } \\
\text { perbedaan pola penyebaran bakteri }\end{array}$ & $\begin{array}{l}\text { terbanyak di temukan di ruang rawat } \\
\text { yang ditemukan di ruang ICU dan ruang }\end{array}$ & $\begin{array}{l}\text { inap Non ICU adalah bakteri } \\
\text { rawat inap Non ICU, jenis bakteri }\end{array}$ & Staphylococcus sp. \\
terbanyak yang ditemukan di ruang & &
\end{tabular}

Tabel 8. Perbedaan pola sensitivitas bakteri terhadap antibiotik di ruang ICU dan ruang Rawat inap Non ICU

\begin{tabular}{clclc}
\hline \multirow{2}{*}{ No. } & \multicolumn{4}{c}{ Antibiotik } \\
\cline { 2 - 5 } & Ruang ICU & $\mathbf{S ( \% )}$ & $\begin{array}{l}\text { Ruang Rawat } \\
\text { Inap Non ICU }\end{array}$ & $\mathbf{S ( \% )}$ \\
\hline 1. & Amikacin & $106(76,6)$ & Amikacin & $302(85)$ \\
2. & Meropenem & $90(67,6)$ & Meropenem & $293(82,5)$ \\
3. & Gentamicin & $84(63)$ & Gentamicin & $198(55,8)$ \\
\hline
\end{tabular}

Berdasarkan tabel di atas di dapatkan hasil penelitian menunjukkan bahwa tidak ada perbedaan pola sensitivitas bakteri terdapat antibiotik di

\section{PEMBAHASAN \\ sampel yang di kelompokan}

ruang ICU dan ruang rawat inap Non ICU ditemukan sensitif terhadap antibiotik amikacin, meropene, dan gentamicin.

berdasarkan ruangan, ruang ICU sebanyak $118 \quad(22,5 \%)$, NICU sebanyak $9(1,7 \%)$, dan ruang PICU 
sebanyak $6(1,1 \%)$. Ruang rawat inap non ICU terdiri dari ruang puri betik hati sebanyak $56(10,7 \%)$, ruang alamanda sebanyak $46(8,8 \%)$, ruang melati sebanyak $41(7,8)$, ruang peri sebanyak $27(5,1 \%)$, ruang kenanga sebanyak $26(5 \%)$, ruang murai sebanyak $23(4,4 \%)$, ruang kutilang sebanyak $22(4,2 \%)$, ruang mawar sebanyak 21 94\%), ruang anyelir sebanyak $17(3,25)$, ruang gelatik dan ruang Vip A masing-masing sebanyak $16(3 \%)$, ruang delima sebanyak 10 $(1,9 \%)$, ruang IGD sebanyak $7(1,3 \%)$, ruang kemuning sebanyak $6(1,1 \%)$, ruang bougenvil sebanyak $4(0,8 \%)$, ruang Tulip, seruni $\mathrm{R} / 14$ dan nuri masing-masing sebanyak $3(0,6 \%)$, ruang isolasi dan anggrek masingmasing sebanyak $2(0,4 \%)$ dan ruang mahan munyai sebanyak $1(0,2 \%)$. Instansi rawat jalan $37(7,0 \%)$.

Dari hasil penelitian Mutia Zahra (2018) di Bandar Lampung, didapatkan jumlah sampel yang dikelompokkan berdasarkan ruangan di RSUD DR.H Abdul Moeloek Provinsi Lampung di dapatkan bakteri terbanyak terdapat di ruang ICU yaitu ICU 65 (22.9\%), NICU $10(3.6 \%)$, dan ruang PICU $9(3.2 \%)$. Ruang non ICU terdiri dari ruang Puri betik hati $39(13.8 \%)$ ruang kutilang 26 $(9.2 \%)$, ruang kenanga $19(6.7 \%)$, ruang alamanda $18(6.3 \%)$, ruang melati dan perinatologi $17(6 \%)$, ruang murai $13(4.6 \%)$, ruang mawar 11 $(3.9 \%)$, ruang kemuning $9(3.2 \%)$, ruang gelatik $8(2.8 \%)$, ruang anyelir 7 $(2.5 \%)$, ruang nuri $3(1.2 \%)$, ruang aster bogenvil dan delima masingmasing $2(0,7 \%)$, ruang Manayun Seruni Tulip dan Vip A masing-masing $1(0,4 \%)$. Instansi rawat jalan 6 (2.1\%).

Hasil yang sama didapatkan dari penelitian sebelumnya berdasarkan data spesimen yang didapat dari hasil kultur di Rumah Sakit Umum Daerah xylosus,

Staphylococcus saprophyticus, Citrobacter freundii, Citrobacter youngae, Proteus hauseri, Yersinia kristensenii, Klebsiella oxytoca, Citrobacter koseri, Pasteurella pneumotropica, Marganella morganii, Serratia ocloriferi, Pseudomonas fluorescens dan Stenotrophomonas mata filii masing-masing $1(0,3 \%)$.
Dr. H. Abdul Moeloek periode JuliDesember 2019 yaitu spesimen pus sebanyak $216 \quad(41,1 \%)$, sputum sebanyak $146 \quad(27,8 \%)$, darah sebanyak $101(19,2 \%)$, cairan tubuh sebanyak $24(4,6 \%)$ dan feses sebanyak $6(1,1 \%)$.

Penelitian yang dilakukan $\mathrm{Ni}$ Nengah (2016) di Denpasar didapatkan spesimen yang hasil kultur positif terbanyak dari sputum(44\%), darah $(28 \%)$, Urin $(12 \%)$ dan pus $(18 \%)$. Dari penelitian Mutia Zahra (2018) di Bandar Lampung didapatkan jumlah sampel terbanyak yaitu sampel pus 170 $(55,2 \%)$, sputum $60(19,5 \%)$, darah 43 $(13,10 \%)$, urin $32(10,4 \%)$ dan cairan tubuh $3(0,97 \%)$. Penelitian yang di lakukan oleh M. Agung Kurnia (2019) di Bandar Lampung di dapatkan jumlah sampel terbanyak dari pus 139 $(48,9 \%)$, sputum $76(26,8 \%)$, darah 45 $(15,8 \%)$, urin $10(3,5 \%)$ dan cairan tubuh $9(2,1 \%)$.

Hasil yang berbeda di dapatkan dari penelitian sebelumnya berdasarkan data pola kuman terbanyak yang di temukan selama periode Juli- Desember 2019 di Rumah Sakit Umum Daerah DR. H. Abdul Moeloek Bandar Lampung, di ruang ICU yaitu bakteri Klebsiella pneumoniae 24 $(18 \%)$ dan yang terendah yaitu bakteri Staphylococcus aureus, Enterococcus faecium, Staphylococcus epidermidis, Serratia marcescens, Providencia stuartii, Pseudomonas fluorescens, Sphigomonas thalpophilum, dan Brukholderia pseudomallei masingmasing $1(0,8 \%)$. Di ruang rawat inap Non ICU ditemukan bakteri terbanyak yaitu bakteri Staphylococcus sp 82 $(23,1 \%)$, dan bakteri yang terendah, yaitu bakteri Salmonella typi, Cronobacter sakazakii, Staphylococcus capitis, Enterococcus faecium, Staphylococcus epidermidis, Staphylococcus lentus, Staphylococcus Berdasarkan penelitian Mutia Zahra (2018) data pola kuman di Rumah Sakit Dr. H. Abdoel Moeloek provinsi Lampung periode Januari - Juli 2016, didapatkan kuman terbanyak di ruangan adalah Staphylococcus sp 134 sampel $(43,5 \%)$, dan yang terendah bakteri Escherichia coli 5 (1,6\%). Dari penelitian M. Agung Kurnia (2019) pola kuman terbanyak yang di temukan 
periode Januari-Maret tahun 2019 di RSUD DR. H. Abdul Moeloek Provinsi Lampung, di ruang ICU adalah Enterobacter cloacae yaitu 6 (33\%), dan yang terendah bakteri Staphylococcus sp, Pseudomonas sp, Yersinia enterocolitica, Morganella morganii, Serratia fonticola, Streptococcus aureus, Seratia fonticola, Acinetobacter baumanii, dan Providencia rettgeri yaitu 1 sampel $(0,4 \%)$, dan di ruang non ICU Enterobacter $s p$ yaitu 51 sampel $(65,3 \%)$, dan yang terendah bakteri Escherichia coli, Staphylococcus aureus, Pseudomonas luteola, Pasteurella pneumotropica, Alcaligenes faecalis, dan Yersinia enterocolitica yaitu 1 sampel $(1,2 \%)$.

Hasil yang didapat dari penelitian ini berbeda dengan penelitian sebelumnya, berdasarkan hasil uji sensitivitas bakteri terhadap antibiotik di Rumah Sakit Umum Daerah Dr. H. Abdul Moeloek Bandar Lampung periode Juli-Desember 2019 di temukan di ruang ICU bakteri terbanyak yaitu bakteri Klebsiella pneumoniae sebanyak 24 sampel dan sensitivitas tertinggi terhadap antibiotik meropenem $22 \quad(91,7 \%)$ dan sensitivitas terendah terhadap sulbactam $(94,2 \%)$ dan di ikuti bakteri Staphylococcus sp sebanyak 20 sampel sensitivitas tertinggi terhadap gentamicin $16 \quad(80 \%)$ sensitivitas terendah clavulanic acid, cefotaxim dan cefedroxil masing-masing 1 (5\%), bakteri Escherichia coli sebanyak 15 sampel sensitivitas tertinggi terhadap meropenem dan amikacin masingmasing $15 \quad(100 \%)$ sensitivitas terendah terhadap tetraciklin $1(50 \%)$, bakteri Enterobacter cloacae sebanyak 12 sampel sensitivitas tertinggi terhadap meropenem dan amikacin masing-masing $11 \quad(\quad 91,7 \%)$ sensitivitas terendah terhadap antibiotik amikacin 37 (100\%), dan sensitivitas terendah terhadap antibiotik Ceftriaxone 2 (100\%). Di ruang ICU Bakteri Enterobacter cloacae memiliki sensitivitas terhadap antibiotik amikacin $37100 \%$, dan sensitivitas terendah terhadap antibiotik ceftriaxone 2 (100\%).

Hasil yang sama dalam penelitian sebelumnya ditemukan perbedaan
Sulbactam dan nitrofurantion masingmasing $2(16,7 \%)$, dan bakteri Pseudomonas aeruginosa sebanyak 10 sampel sensitivitas tertinggi terhadap amikacin $10 \quad(100 \%)$ sensitivitas terendah terhadap ceftriaxone dan sulfamethoxazole masing-masing 1 (50\%). Di ruang rawat inap Non ICU ditemukan bakteri terbanyak yaitu bakteri Staphylococcus sp sebanyak 82 sampel sensitivitas tertinggi terhadap meropenem $74 \quad(90,2 \%)$ sensitivitas terendah terhadap eritromicin $2(2,4 \%)$ di ikuti bakteri Escherichia coli sebanyak 39 sampel sensitivitas tertinggi terhadap amikacin 39 (100\%) sensitivitas terendah terhadap ampicillin $1(2,6 \%)$, bakteri Klebsiella pneumoniae sebanyak 32 sampel sensitivitas tertinggi terhadap amikacin $28(87,5 \%)$ sensitivitas terendah terhadap nitrofurantion 7 (22\%), bakteri Enterobacter cloacae sebanyak 31 sampel sensitivitas tertinggi terhadap amikacin $31 \quad(100 \%)$ sensitivitas terendah terhadap cefazolin $3(9,7 \%)$ dan bakteri Enterobacter $s p$ sebanyak 22 sampel memiliki sensitivitas tertinggi terhadap meropenem dan amikacin masingmasing 20 (90,9\%).

Berdasarkan penelitian Mutia Zahra (2018) di Rumah Sakit Dr. H. Abdoel Moeloek provinsi Lampung periode Januari - Juli 2016, didapatkan hasil uji sensitivitas terhadap antibiotik didapatkan pola bakteri yang sudah resisten adalah Penisilin (100\%), Ampisilin (83\%), Amoksilin (78,6\%), dan Cefotaxime (33\%). Berdasarkan hasil penelitian M. Agung Kurnia (2019) untuk uji sensitivitas bakteri di Rumah Sakit Dr. H. Abdoel Moeloek provinsi Lampung periode Januari-Maret 2019 yang di temukan di ruang non ICU bakteri Enterobacter $s p$ sensitivitas tertinggi terhadap

perbandingan pola sensitivitas bakteri terhadap antibiotik yang mana di runang ICU bakteri Staphylococcus $s p$ sensitif terhadap gentamicin 16 (80\%) sedangkan di ruang rawat inap Non ICU sensitif terhadap meropenem 74 $(90,2 \%)$. Bakteri Klebsiella pneumoniae di ruang ICU sensitif terhadap antibiotik meropenem 22 $(91,7 \%)$ dan di ruang Non ICU sensitif 
terhadap Amikacin 28 (87,5\%). Bakteri Enterobacter cloacaes di ruang ICU sensitif terhadap antibiotik meropenam dan amikacin $11(91,7 \%)$ dan di ruang Non ICU sensitif terhadap Amikacin 31 (100\%). Namun untuk bakteri Escherichia coli memiliki sensitivitas yang sama terhadap antibiotik amikacin 15 (80\%) dan 39 (100\%).

Berdasarkan hasil penelitian $M$. Agung Kurnia (2019) untuk uji sensitivitas bakteri di Rumah Sakit Dr. H. Abdoel Moeloek provinsi Lampung periode Januari-Maret 2019 terlihat bahwa ada perbedaan pola sensitivitas bakteri terhadap antibiotik yang di temukan di ruang ICU dan ruang non ICU, dimana di ruang ICU di temukan bakteri Enterobacter $s p$ sensitivitas tertinggi terhadap antibiotik amikacin $37(100 \%)$, dan sensitivitas terendah terhadap antibiotik ceftriaxone 2 $(100 \%)$. Di ruang ICU Bakteri Enterobacter cloacae memiliki sensitivitas terhadap antibiotik amikacin $37100 \%$, dan sensitivitas terendah terhadap antibiotik ceftriaxone 2 (100\%).

\section{KESIMPULAN}

Perbandingan pola sensitivitas bakteri terhadap antibiotik di ruang ICU dan ruang rawat inap Non ICU di Rumah Sakit Umum Daerah Dr. H. Abdul Moeloek Bandar Lampung periode Juli-Desember 2019 didapatkan:

Data kultur jenis bakteri yang terdapat di ruang ICU didapatkan bakteri terbanyak adalah Klebisella pneumoniae 24 (18\%), Staphylococcus sp 20 (15\%), Escherichia coli 15 (11,3\%) dan Enterobacter cloacae 12 $(9 \%)$, dan didapatkn bakteri terendah, yaitu Staphylococcus aureus, Non ICU tidak terdapat perbedaan, baik ruang ICU dan ruang rawat inap non ICU memiliki sensitivitas tertinggi terhadap antibiotik amikacin, meropenem dan gentamicin.

\section{SARAN}

Perlu dilakukan penelitian tentang pola sensitivitas bakteri di rumah sakit lainnya untuk mengetahui bakteri yang
Enterococcus faecium, Staphylococcus epidermidis, Serratia marcescens, Providencia stuartii, Pseudomonas fluorescens, Sphingomonas thalpophilum, dan Brukholderia pseudomallei masing-masing $1(0,8 \%)$.

Dari data kultur jenis bakteri yang terdapat di ruang rawat inap Non ICU didapatkan bakteri terbanyak, yaitu Staphylococcus sp $82 \quad(23,1 \%)$, Escherichia coli $39(11 \%)$, Klebsiella pneumoniae 32 (9\%), Enterobacter cloacae $31(8,7 \%)$ dan Enterobacter $s p$ $22(6,2 \%)$ dan didapatkan bakteri terendah, yaitu bakteri Salmonella typi, Cronobacter sakazakii, Staphylococcus capitis, Enterococcus faecium, Staphylococcus epidermidis, Staphylococcus lentus, Staphylococcus xylosus, Staphylococcus saprophyticus, Citrobacter freundii, Citrobacter youngae, Proteus hauseri, Yersinia kristensenii, Klebsiella oxytoca Citrobacter koseri, Pasteurella pneumotropica, Marganella morganii, Serratia ocloriferi, Pseudomonas fluorescens dan Stenotrophomonas mata filii masing-masing $1(0,3 \%)$.

Data hasil kultur selama periode Juli-Desember 2019 ditemukan pola sensitivitas bakteri pada ruang rawat inap Non ICU yaitu bakteri terbanyak di ruang ICU adalah Klebsiella pneumoniae $24 \quad(18 \%)$ dengan sensitivitas tertinggi terhadap antibiotik Meropenam $(91,7 \%)$ sedangkan pada ruang rawat inap Non ICU bakteri terbanyak adalah Staphylococcus $s p$ dengan sensitivitas tertinggi terhadap Meropenem $(90,2 \%)$.

Diketahui terdapat perbedaan pola penyebaran bakteri yang ditemukan di ruang ICU dan ruang rawat inap Non ICU. Untuk pola sensitivitas bakteri terhadap antibiotik antara ruang ICU dan ruang rawat inap

masih sensitif dan bakteri yang sudah resisten terhadap antibiotik.

\section{DAFTAR PUSTAKA}

Kemenkes RI. (2010). Pedoman Penyelenggaraan Pelayanan Intensive Care Unit (ICU) di Rumah Sakit. No,1778. Jakarta

Kemenkes RI. (2019). Komitmen Stakeholder Dalam Upaya 
Pengendalian Resistensi

Antimikroba di Fasyankes.

Manado.

Kurnia. (2020). Perbandingan Pola

Sensitivitas Bakteri Terhadap

Antibiotik Antara Ruang ICU dan

Non ICU di Rumah Sakit Umum

Daerah DR.H. Abdul Moeloek

Provinsi Lampung Periode

Januari-Maret Tahun 2019. Jurnal

Medika.4(1):54-59.

Nenggah DF. (2016). Pola Mikroba

Pasien Yang Dirawat di Intensive

Care Unit (ICU) Serta Kepekaanya

Terhadap Antibiotik di RSUP

Sanglah Denpasar Bali Agustus-

Oktober 2013. E-Jurnnal Medika. 5(4): 2-4.

Riskesdas. (2013). Badan Penelitian dan pengembangan Kesehatan Kementerian Kesehatan RI. Jakarta.

Utami P. (2012). Antibiotik Alami Untuk Mengatasi Aneka Penyakit. Jakarta :PT Agromedia Pustaka.

WHO. 2011. Collaborating Centre For Drug Statistics Methodology ATC/DDD Index 2011.

Wiguna DS. (2016). Pola Resistensi Bakteri Terhadap Antibiotik Pada Penderita Infeksi Luka Operasi (ILO) Di Rumah Sakit X Periode Agustus 2013-Agustus 2015. Skripsi. Program Studi Farmasi Universitas Muhamadiyah Suryakarta. Suryakarta.

Zahrah M. (2018). Analisis Pola Kuman dan Pola Resistensi Pada Hasil Pemeriksaan Kultur Resistensi di Laboratorium Patologi Klinik Rumah Sakit Dr. H. Abdoel Moeloek Provinsi Lampung Periode Januari-Juli 2016. Jurnal Ilmu Kedokteran dan Kesehatan. 5(2): 80-83. 